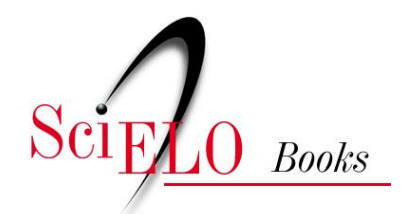

\title{
XV - Influências sociais e políticas da escravidão
}

\author{
Joaquim Nabuco
}

\section{SciELO Books / SciELO Livros / SciELO Libros}

NABUCO, J. Influências sociais e políticas da escravidão. In: $O$ abolicionismo [online]. Rio de Janeiro: Centro Edelstein de Pesquisas Sociais, 2011. Influências sociais e políticas da escravidão. pp. 110-128. ISBN: 978-85-7982-070-0. https://doi.org/10.7476/9788579820700.0016.

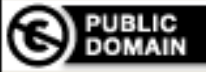

This work is free of known copyright restrictions. http://creativecommons.org/publicdomain/mark/1.0/

Este trabalho está livre de restrições de direito de autor e/ou de direitos conexos conhecidas.

http://creativecommons.org/publicdomain/mark/1.0/

Esta obra está libre de restricciones conocidas de derechos autorales. http://creativecommons.org/publicdomain/mark/1.0/ 


\section{XV - INFLUÊNCIAS SOCIAIS E POLÍTICAS DA ESCRAVIDÃO}

Não é somente como instrumento produtivo que a escravidão é apreciada pelos que a sustentam. É ainda mais pelos seus resultados políticos e sociais, como o meio de manter uma forma de sociedade na qual os senhores de escravos são os únicos depositários do prestígio social e poder político, como a pedra angular de um edifício do qual eles são os donos, que esse sistema é estimado. Aboli a escravidão e introduzireis uma nova ordem de coisas.

Professor Cairnes

Depois da ação que vimos do regime servil, sobre o território e a população, os seus efeitos sociais e políticos são meras consequências. Um governo livre, edificado sobre a escravidão, seria virgem na história. Os governos antigos não foram baseados sobre os mesmos alicerces da liberdade individual que os modernos, e representam uma ordem social muito diversa. Só houve um grande fato de democracia combinadas com a escravidão, depois da Revolução Francesa - os Estados Unidos; mas os estados do sul nunca foram governos livres. A liberdade americana, tomada a União como um todo, data, verdadeiramente, da proclamação de Lincoln que declarou livre os milhões de escravos do Sul. Longe de serem países livres, os estados ao sul do Potomac eram sociedades organizadas sobre a violação de todos os direitos da humanidade. Os estadistas americanos, como Henry Clay e Calhoun, que transigiram ou se identificaram com a escravidão, não calcularam a força do antagonismo que devia, mais tarde, revelar-se tão formidável. O que aconteceu - a rebelião na qual o Sul foi salvo pelo braço do Norte do suicídio que ia cometer, separando-se da União para formar uma potência escravagista, e o modo pelo qual ela foi esmagada - prova que nos Estados Unidos a escravidão não afetara a constituição social toda, como entre nós; mas deixara a parte superior do organismo intacta, e forte ainda bastante para curvar a parte até então dirigente à sua vontade, apesar de toda a cumplicidade com essa.
Entre nós, não há linha alguma divisória. Não há uma seção do país que seja diversa da outra. O contato foi sinônimo de contágio. A circulação geral, desde as grandes artérias até aos vasos capilares, serve de canal às mesmas impurezas. O corpo todo - sangue, elementos constitutivos, respiração, forças e atividade, músculos e nervos, inteligência e vontade, não só o caráter, senão o temperamento, e mais do que tudo a energia acha-se afetado pela mesma causa.

Não se trata, somente, no caso da escravidão no Brasil, de uma instituição que ponha fora da sociedade um imenso número de indivíduos, como na Grécia ou na Itália antiga, e lhes dê por função social trabalhar para os cidadãos; trata-se de uma sociedade não só baseada, como era a civilização antiga, sobre a escravidão, e permeada em todas as classes por ela, mas também constituída, na sua maior parte, de secreções daquele vasto aparelho.

Com a linha divisória da cor, assim era, por exemplo, nos estados do Sul da União. Os escravos e os seus descendentes não faziam parte da sociedade. A escravidão misturava, confundia, a população em escala muito pequena. Estragava o solo, impedia as indústrias, preparava a bancarrota econômica, afastava a imigração, produzia, enfim, todos os resultados dessa ordem que vimos no Brasil; mas a sociedade americana não era formada de unidades criadas por esse processo. A emenda constitucional, alterando tudo isso incorporou os negros na comunhão social, e mostrou como são transitórias as divisões que impedem artificialmente as raças ou classes de tomar o seu nível natural.

Mas, enquanto durou a escravidão, nem os escravos nem os seus descendentes livres concorreram, de forma alguma, para a vida mental ou ativa dessa sociedade parasita que eles tinham o privilégio de sustentar com o seu sangue. Quando veio a abolição, e depois dela a igualdade de direitos políticos, a Virgínia e a Geórgia viram, de repente, todas as altas funções do Estado entregues a esses mesmos escravos, que eram, até então, socialmente falando, matéria inorgânica, e que, por isso, só podiam servir nesse primeiro ensaio de vida política para instrumentos de especuladores adventícios, como os carpetbaggers. Esse período, entretanto, pode ser considerado como a continuação da guerra civil. A separação das duas raças, que fora o sistema adotado pela escravidão norte-americana mantida por uma antipatia à cor preta, que foi sucessivamente buscar fundamentos na maldição de Cham e na teoria da evolução pitecóide, e por 
princípios severos de educação -, continua a ser o estado das relações entre os dois grandes elementos de população nos estados do Sul.

No Brasil deu-se exatamente o contrário. A escravidão, ainda que fundada sobre a diferença das duas raças, nunca desenvolveu a prevenção da cor, e nisso foi infinitamente mais hábil. Os contatos entre aquelas, desde a colonização primitiva dos donatários, e os escravos, ao receberem sua carta de alforria, recebiam também a investidura de cidadão. Não há assim, entre nós, castas sociais perpétuas, não há mesmo divisão fixa de classes. $\mathrm{O}$ escravo, que, como tal, praticamente não existe para a sociedade, porque o senhor pode não o ter matriculado e, se o matriculou, pode substituí-lo, e a matrícula mesmo nada significa, desde que não há inspeção do Estado nas fazendas, nem os senhores são obrigados a dar contas dos seus escravos às autoridades. Esse ente, assim equiparado, quanto à proteção social, a qualquer outra coisa de domínio particular, é, no dia seguinte à sua alforria, um cidadão como outro qualquer, com todos os direitos políticos, e o mesmo grau de elegibilidade. Pode mesmo, ainda na penumbra do cativeiro, comprar escravos, talvez, quem sabe? - algum filho do seu antigo senhor. Isso prova a confusão de classes e indivíduos, e a extensão ilimitada dos cruzamentos sociais entre escravos e livres, que fazem da maioria dos cidadãos brasileiros, se se pode assim dizer, mestiços políticos, nos quais se combatem duas naturezas opostas: a do senhor de nascimento e a do escravo domesticado.

A escravidão, entre nós, manteve-se aberta e estendeu os seus privilégios a todos indistintamente: brancos ou pretos, ingênuos ou libertos, escravos mesmo, estrangeiros ou nacionais, ricos ou pobres; e, dessa forma, adquiriu, ao mesmo tempo, uma força de absorção dobrada e uma elasticidade incomparavelmente maior do que houvera tido se fosse um monopólio de raça, como nos estados do Sul. Esse sistema de igualdade absoluta abriu, por certo, um melhor futuro à raça negra, do que era o seu horizonte na América do Norte. Macaulay disse na Câmara dos Comuns em 1845, ano do bill Aberdeen: "Eu não julgo improvável que a população preta do Brasil seja livre e feliz dentro de oitenta ou cem anos. Não vejo porém perspectiva razoável de igual mudança nos Estados Unidos”. Essa intuição da felicidade relativa da raça nos dois países parece hoje ser tão certa quanto provou ser errada a suposição de que os Estados Unidos tardariam mais do que nós a emancipar os seus escravos. $\mathrm{O}$ que enganou, nesse caso, o grande orador inglês foi o preconceito de cor, que se lhe afigurou ser uma força política e social para a escravidão, quando, pelo contrário, a força desta consiste em banir tal preconceito e em abrir a instituição a todas as classes. Mas, por isso mesmo, entre nós, o caos étnico foi o mais gigantesco possível, e a confusão reinante nas regiões em que se está elaborando, com todos esses elementos heterogêneos, a unidade nacional faz pensar na soberba desordem dos mundos incandescentes.

Atenas, Roma, a Virgínia, por exemplo, foram, tomando uma comparação química, simples misturas nas quais os diversos elementos guardavam as suas propriedades particulares; o Brasil, porém, é um composto, do qual a escravidão representa uma afinidade casual. O problema que nós queremos resolver é o de fazer desse composto de senhor e escravo um cidadão. O dos estados do Sul foi muito diverso, porque essas duas espécies não se misturaram. Entre nós a escravidão não exerceu toda a sua influência apenas abaixo da linha romana da libertas; exerceu-a, também, dentro e acima da esfera da civitas; nivelou, exceção feita dos escravos, que vivem sempre nos subterrâneos sociais, todas as classes; mas nivelou-as degradando-as. Daí a dificuldade, ao analisar-lhe a influência, de descobrir um ponto qualquer, ou na índole do povo, ou na face do país, ou mesmo nas alturas mais distantes das emanações das senzalas, sobre que, de alguma forma, aquela afinidade não atuasse, e que, não deva ser incluída na síntese nacional da escravidão. Vejam-se as diversas classes sociais. Todas elas apresentam sintomas de desenvolvimento ou retardado ou impedido, ou, o que é ainda pior, de crescimento prematuro artificial. Estudem-se as diversas forças, ou que mantêm a hereditariedade nacional ou que lhe dirigem a evolução, e ver-se-á que as conhecidas se estão todas enfraquecendo, e que tanto a conservação, como o progresso do país são problemas atualmente insolúveis, dos quais a escravidão, e só ela, é a incógnita. Isso tudo, tenho apenas espaço para apontar, não para demonstrar.

Uma classe importante, cujo desenvolvimento se acha impedido pela escravidão, é a dos lavradores que não são proprietários, e, em geral, dos moradores do campo ou do sertão. Já vimos a que se acha, infelizmente, reduzida essa classe, que forma a quase totalidade da nossa população. Sem independência de ordem alguma, vivendo ao azar do capricho alheio, as palavras da oração dominical: $O$ pão nosso de cada dia, nos dai hoje têm para ela uma significação concreta e real. Não se trata de operários, que, 
expulsos de uma fábrica, achem lugar em outra; nem de famílias que possam emigrar; nem de jornaleiros que vão ao mercado de trabalho oferecer os seus serviços; trata-se de uma população sem meios, nem recurso algum, ensinada a considerar o trabalho com uma ocupação servil, sem ter onde vender os seus produtos, longe da região do salário - se existe esse Eldorado, em nosso país - e que por isso tem que resignar-se a viver e criar os filhos, nas condições de dependência e miséria em que se lhe consente vegetar.

Esta é uma pintura que, com verdadeiro sentimento humano, fez de uma porção, e a mais feliz, dessa classe, um senhor de engenho no Congresso Agrícola do Recife em 1878:

O plantador não fabricante leva vida precária; seu trabalho não é remunerado, seus brios não são respeitados; seus interesses ficam à mercê dos caprichos do fabricante em cujas terras habita. Não há ao menos um contrato escrito, que obrigue as partes interessadas; tudo tem base na vontade absoluta do fabricante. Em troca de habitação, muitas vezes péssima, e de algum terreno que lhe é dado para plantações de mandioca, que devem ser limitadas, e feitas em terreno sempre o menos produtivo; em troca disto, parte o parceiro todo o açúcar de suas canas em quantidades iguais; sendo propriedade do fabricante todo mel de tal açúcar, toda a cachaça delas resultante, todo o bagaço, que é excelente combustível para o fabrico do açúcar, todos os olhos das canas, suculento alimento para o seu gado. É uma partilha leonina, tanto mais injusta quanto todas as despesas de plantação, trato da lavoura, corte, arranjo das canas e seu transporte à fábrica, são feitas exclusivamente pelo plantador meeiro.

À parte os sentimentos do que são equitativos e generosos, o pobre plantador de canas da classe a que me refiro, nem habitação segura tem: de momento para outro pode ser caprichosamente despejado, sujeito a ver estranhos até a porta da cozinha de sua triste habitação, ou a precipitar a sua saída, levando à família o último infortúnio. ${ }^{45}$

Essa é ainda uma classe favorecida, a dos lavradores meeiros, abaixo da qual há outras que nada têm de seu, moradores que nada têm para vender ao proprietário, e que levam uma existência nômade e segregação de todas as obrigações sociais, como fora de toda a proteção do Estado.

\footnotetext{
${ }^{45}$ Congresso Agrícola do Recife, p. 323-324, observações do Sr. A. Vitor de Sá Barreto.
}

Tomem-se outras classes, cujo desenvolvimento se acha retardado pela escravidão, as classes operárias e industriais, e, em geral, o comércio.

A escravidão não consente, em parte alguma, classes operárias propriamente ditas, nem é compatível com o regime do salário e a dignidade pessoal do artífice. Este mesmo, para não ficar debaixo do estigma social que ela imprime nos seus trabalhadores, procura assinalar o intervalo que o separa do escravo, e imbui-se assim de um sentimento de superioridade, que é apenas baixeza de alma, em quem saiu da condição servil, ou esteve nela por seus pais.

Além disso, não há classes operárias fortes, respeitadas, e inteligentes, onde os que empregam trabalho estão habituados a mandar escravos. Também os operários não exercem entre nós a mínima influência política ${ }^{46}$.

Escravidão e indústria são termos que se excluíram sempre, como escravidão e colonização. $\mathrm{O}$ espírito da primeira, espalhando-se por um país, mata cada uma das faculdades humanas, de que provém a indústria: a iniciativa, a invenção, a energia individual; e cada um dos elementos de que ela precisa: a associação de capitais, a abundância de trabalho, a educação técnica dos operários, a confiança no futuro. No Brasil, a indústria agrícola é a única que tem florescido em mãos de nacionais. O comércio só tem prosperado nas de estrangeiros. Mesmo assim, veja-se qual é o estado da lavoura, como adiante o descrevo. Está, pois, singularmente retardado em nosso país o período industrial, no qual vamos apenas agora entrando.

O grande comércio nacional não se dispõe de capitais comparáveis aos do comércio estrangeiro, tanto de exportação como de importação, ao passo que o comércio a retalho, em toda a sua porção florescente, com vida própria, por assim dizer consolidada, é praticamente monopólio de estrangeiros. Esse fato provocou, por diversas vezes em nossa história, manifestações populares, com a bandeira da nacionalização do comércio a retalho. Mas, tal grito caracteriza o espírito de exclusivismo e ódio à

\footnotetext{
${ }^{46}$ A seguinte distribuição dos eleitores do Município Neutro em 1881 mostra bem qual é a representação de operários que temos. Dos 5.928 eleitores que representavam a capital do país, havia 2.211 empregados públicos, civis ou militares, 1.076 negociantes ou empregados do comércio, 516 proprietários, 398 médicos, 211 advogados, 207 engenheiros, 179 professores, 145 farmacêuticos, 236 artistas, dividindo-se o resto por diversas profissões, como clérigos (76), guarda-livros (58), despachantes (56), solicitadores (27), etc. Esses algarismos dispensam qualquer comentário.
} 
concorrência, por mais legítima que sejam em que a escravidão educou o nosso povo, e, em mais de um lugar, foi acompanhado de sublevações do mesmo espírito atuando em outra direção, isto é, do fanatismo religioso. Não sabiam os que sustentavam aquele programa do fechamento dos portos do Brasil, e da anulação de todo o progresso que temos feito desde 1808 , que, se tirassem o comércio a retalho aos estrangeiros, não o passariam para os nacionais, mas simplesmente o reduziriam a uma carestia de gêneros permanente - porque é a escravidão, e não a nacionalidade, que impede o comércio a retalho de ser em grande parte brasileiro.

Em relação ao comércio, a escravidão procede desta forma: fechalhe, por desconfiança e rotina, o interior, isto é, tudo o que não é a capital da província; exceto em Santos e Campinas, em São Paulo; Petrópolis e Campos no Rio de Janeiro; Pelotas, no Rio Grande do Sul; e alguma outra cidade mais, não há casa de negócio senão nas capitais, onde se encontre mais do que um pequeno fornecimento de artigos necessários à vida, esses mesmos ou grosseiros ou falsificados. Assim como nada se vê que revele o progresso intelectual dos habitantes - nem livrarias, nem jornais - não se encontra o comércio, senão na antiga forma rudimentar, indivisa ainda, da venda-bazar. Por isso, o que não vai diretamente da Corte, como encomenda, só chega ao consumidor pelo mascate, cuja história é a da civilização do nosso interior todo, e que, de fato, é o pioneer do comércio, e representa os limites em que a escravidão é compatível com a permuta local. O comércio, entretanto, é o manancial da escravidão, e o seu banqueiro. $\mathrm{Na}$ geração passada, em toda a parte, ele a alimentou de africanos boçais ou ladinos; muitas das propriedades agrícolas caíram em mãos de fornecedores de escravos; as fortunas realizadas pelo tráfico (para o qual a moeda falsa teve por vezes grande afinidade) foram, na parte não exportada, nem convertida em pedra e cal, empregadas em auxiliar a lavoura pela usura. $\mathrm{Na}$ atual geração, o vínculo entre o comércio e a escravidão não é assim desonroso para aquele; mas a dependência mútua continua a ser a mesma. Os principais fregueses do comércio são proprietário de escravos, exatamente como os leaders da classe; o café é sempre rei nas praças do Rio e de Santos, e o comércio, faltando a indústria e o trabalho livre, não pode servir senão para agente da escravidão, comprando-lhe tudo o que ela oferece e vendendo-lhe tudo de que ela precisa. Por isso também no Brasil ele não se desenvolve, não abre horizontes ao país; mas é uma força inativa, sem estímulos, e cônscia de que é, apenas, um prolongamento da escravidão, ou antes o mecanismo pelo qual a carne humana é convertida em ouro e circula, dentro e fora do país, sob a forma de letras de câmbio. Ele sabe que, se a escravidão o receia, como receia todos os condutores do progresso, seja este a loja do negociante, a estação da estrada de ferro, ou a escola primária, também precisa dele, como por certo não precisa, nem quer saber desta última, e trata de viver com ela nos melhores termos possíveis. Mas, com a escravidão, o comércio será sempre o servo de uma classe, sem a independência de um agente nacional; ele nunca há de florescer num regime que não lhe consente entrar em relações diretas com os consumidores, e não eleva a população do interior a essa categoria.

Das classes que esse sistema fez crescer artificialmente a mais numerosa é a dos empregados públicos. A estreita relação entre a escravidão e a epidemia do funcionalismo não pode ser mais contestada que a relação ente ela e a superstição do Estado-providência. Assim como, nesse regime, tudo se espera do Estado, que, sendo a única associação ativa, aspira e absorve pelo imposto e pelo empréstimo todo o capital disponível e distribui-o, entre os seus clientes, pelo emprego público, sugando as economias do pobre pelo curso forçado, e tornando precária a fortuna do rico; assim também, como consequência, o funcionalismo é a profissão nobre e a vocação de todos. Tomem-se, ao acaso, vinte ou trinta brasileiros em qualquer lugar onde se reúna a nossa sociedade mais culta; todos eles ou foram ou são, ou hão de ser, empregados públicos; se não eles, seus filhos.

O funcionalismo é, como já vimos, o asilo dos descendentes das antigas famílias ricas e fidalgas, que desbarataram as fortunas realizadas pela escravidão, fortunas a respeito das quais pode-se dizer, em regra, como se diz das fortunas feitas no jogo, que não medram nem dão felicidade. É além disso o viveiro político, porque abriga todos os pobres inteligentes, todos os que tem ambição e capacidade, mas não tem meios, e que são a grande maioria dos nossos homens de merecimento. Faça-se uma lista dos nossos estadistas pobres, de primeira e de segunda ordem, que resolveram o seu problema individual pelo casamento rico, isto é, na maior parte dos casos, tornando-se humildes clientes da escravidão; e outra dos que o resolveram pela acumulação de cargos públicos, e ter-se-ão, nessas duas listas, os nomes de quase todos eles. Isso significa que o país está fechado em todas as direções; que muitas avenidas que poderiam oferecer um meio 
de vida a homens de talento, mas sem qualidades mercantis, como a literatura, a ciência, a imprensa, o magistério, não passam ainda de vielas, e outras, em que homens práticos, de tendências industriais, poderiam prosperar, são por falta de crédito, ou pela estreiteza do comércio, ou pela estrutura rudimentar da nossa vida econômica, outras tantas portas muradas.

Nessas condições oferecem-se ao brasileiro que começa diversos caminhos, os quais conduzem todos ao emprego público. As profissões chamadas independentes, mas que dependem em grande escala do favor da escravidão, como a advocacia, a medicina, a engenharia, têm pontos de contato importantes com o funcionalismo, como sejam os cargos políticos, as academias, as obras públicas. Alem desses, que recolhem por assim dizer as migalhas do orçamento, há outros, negociantes, capitalistas, indivíduos inclassificáveis, que querem contratos, subvenções do Estado, garantias de juro, empreitadas de obras, fornecimentos públicos.

A classe dos que assim vivem com os olhos voltados para a munificência do governo é extremamente numerosa, e diretamente filha da escravidão, porque ele não consente outra carreira aos brasileiros, havendo abarcado a terra, degradado o trabalho, corrompido o sentimento de altivez pessoal em desprezo por quem trabalha em posição inferior a outro, ou não faz trabalhar. Como a necessidade é irresistível, essa fome de emprego público determina uma progressão constante do nosso orçamento, que a nação, não podendo pagar com a sua renda, paga com o próprio capital necessário à sua subsistência e que, mesmo assim, só é afinal equilibrado por novas dívidas.

Além de ser artificial e prematuro, o atual desenvolvimento da classe dos remunerados pelo Tesouro, sendo, como é a cifra da despesa nacional, superior às nossas forças, a escravidão, fechando todas as outras avenidas, como vimos, da indústria, do comércio, da ciência, das letras, criou em torno desse exército ativo uma reserva de pretendentes, cujo número realmente não se pode contar, e que, com exceção dos que estão consumindo, ociosamente, as fortunas que herdaram e dos que estão explorando a escravidão com alma do proprietário de homens, pode calcular-se, quase exatamente, pelo recenseamento dos que sabem ler e escrever. Num tempo em que o servilismo e a adulação são a escala pela qual se sobe, e a independência e o caráter a escada pela qual se desce; em que a inveja é uma paixão dominante; em que não há outras regras de promoção, nem provas de suficiência, senão o empenho do patronato; quando ninguém, que não se faça lembrar, é chamado para coisa alguma, e a injustiça é ressentida apenas pelo próprio ofendido: os empregados públicos são os servos da gleba do governo; vivem com suas famílias em terras do Estado, sujeitos a uma evicção sem aviso, que equivale à fome, numa dependência da qual só para os fortes não resulta a quebra do caráter. Em cada um dos sintomas característicos da séria hipertrofia do funcionalismo, como ela se apresenta no Brasil, quem tenha estudado a escravidão reconhece logo um dos seus efeitos. Podemos nós, porém, ter a consolação de que abatendo as diversas profissões, reduzindo a nação ao proletariado, a escravidão todavia conseguiu fazer do senhores, da lavoura, uma classe superior, pelo menos rica, e, mais do que isso, educada, patriótica, digna de representar o país intelectual e moralmente.

Quanto à riqueza, já vimos que a escravidão arruinou uma geração de agricultores, que ela mesma substituiu pelos que lhes forneciam os escravos. De 1853 a 1857, quando se deviam estar liquidando as obrigações do tráfico, a dívida hipotecária da Corte e província do Rio de Janeiro subia a sessenta e sete mil contos. A atual geração não tem sido mais feliz. Grande parte dos seus lucros foram convertidos em carne humana, a alto preço, e, se hoje uma epidemia devastasse os canaviais, o capital que a lavoura toda do Império poderia apurar para novas culturas havia de espantar os que a reputam florescente. Além disso, há quinze anos que não se fala senão em auxílios à lavoura. Tem a data de 1868 um opúsculo do Sr. Quintino Bocaiúva, A crise da lavoura, em que esse notável jornalista escrevia:

A lavoura não se pode restaurar senão pelo efeito simultâneo de dois socorros que não podem mais ser demorados - o da instituição do crédito agrícola e o da aquisição e braços produtores.

O primeiro socorro era "uma vasta emissão" sobre a propriedade predial do Império, que assim seria convertida em moeda corrente; o segundo era a colonização chinesa.

Há quinze anos que se nos descreve de todos os lados a lavoura como estando em crise, necessitando de auxílio, agonizante, em bancarrota próxima. O Estado é, todos os dias, denunciado por não fazer empréstimos e aumentar os impostos para habilitar os fazendeiros a comprar ainda mais escravos. Em 1875 uma lei, a de 6 de novembro, autorizou o governo a dar a garantia nacional ao banco estrangeiro - nenhum outro poderia emitir na 
Europa - que emprestasse dinheiro à lavoura mais barato do que o mercado monetário interno. Para terem fábricas centrais de açúcar, e melhorarem o seu produto, os senhores de engenho precisaram que a nação as levantasse sob sua responsabilidade. O mesmo tem-se pedido para o café. Assim como dinheiro a juro barato e engenhos centrais, a chamada grande propriedade exige fretes de estrada de ferro à sua conveniência, exposições oficiais de café, dispensa de todo e qualquer imposto direto, imigração asiática, e uma lei de localização de serviços que faça do colono, alemão, ou inglês, ou italiano, um escravo branco. Mesmo a população nacional tem que ser sujeita a um novo recrutamento agrícola, ${ }^{47}$ para satisfazer diversos Clubs, e, mais que tudo, o câmbio, por uma falência econômica, tem que ser conservado tão baixo quanto possível, para o café, que é pago em ouro, valer mais papel.

Também a horrível usura de que é vítima a lavoura em diversas províncias, sobretudo no Norte, é a melhor prova do mau sistema que a escravidão fundou, e do qual duas características principais - a extravagância e o provisório - são incompatíveis com o crédito agrícola que ela reclama. "A taxa dos juros dos empréstimos à lavoura pelos seus correspondentes" é o extrato oficial das informações prestada pelas presidências de províncias em 1874, "regula em algumas províncias de 7 a 17\%; em outras sobre de 18 a 24\%", e "há exemplo de se cobrar de 48 a $72 \%$ anualmente!" Como não se pretende que a lavoura renda mais de $10 \%$, e toda ela precisa de capitais a juro, essa taxa quer simplesmente dizer - a bancarrota. Não é, por certo, essa a classe que se pode descrever em estado próspero e florescente, e que se pode chamar rica.

\footnotetext{
${ }^{47}$ O Club da Lavoura e Comércio de Taubaté, por exemplo, incumbiu uma comissão de estudar a lei de locação de serviços, e o resultado desse estudo foi um projeto cujo primeiro artigo obrigava a contratação de serviços todo o nacional de doze anos para cima que fosse encontrado sem ocupação honesta. Esse nacional teria a escolha de ser recrutado para o exército, ou de contratar seus serviços com algum lavrador de sua aceitação. $\mathrm{O}$ art. $6^{\circ}$ dispunha: "O locador que bem cumprir seu contrato durante os cinco anos terá direito, afinal, a um prêmio pecuniário que não excederá os $500 \$ 000$. Parágrafo $1^{\circ}$. Este prêmio será pago pelo governo em dinheiro ou em apólice da dívida pública”. A escravidão tem engendrado tanta extravagância que não sei dizer se essa é a maior de todas. Mas assim como Valença se obstina em ser a Esparta, a Corte a Delos, a Bahia a Corinto, dir-se-á, à vista desse prêmio de $500 \$$, que se quer fazer de Taubaté, que J. M. de Macedo nos descreve como "antiga, histórica e orgulhosa do seu passado" - a Beócia, da escravidão.
}

Quanto às suas funções sociais, uma aristocracia territorial pode servir ao país de diversos modos: melhorando e desenvolvendo o bem estar da população que a cerca e o aspecto do país em que estão encravados os seus estabelecimentos; tomando a direção do progresso nacional; cultivando, ou protegendo, as letras e as artes; servindo no exército e na armada, ou distinguindo-se nas diversas carreiras; encarnando o que há de bom no caráter nacional, ou as qualidades superiores do país, o que mereça ser conservado como tradição. Já vimos o que a nossa lavoura conseguiu em cada um desses sentidos, quando notamos o que a escravidão administrada por ela há feito do território e do povo, dos senhores e dos escravos. Desde que a classe única, em proveito da qual ela foi criada e existe, não é a aristocracia do dinheiro, nem a do nascimento, que papel permanente desempenha no Estado uma aristocracia heterogênea e que nem mesmo mantém a sua identidade por duas gerações?

Se, das diversas classes, passamos às forças sociais, vemos que a escravidão ou as apropriou aos seus interesses, quando transigentes, ou fez em torno delas o vácuo, quando inimigas, ou lhes impediu a formação, quando incompatíveis.

Entre as que se identificaram, desde o princípio, com ela, tornando-se um dos instrumentos das suas pretensões, está, por exemplo, a Igreja. No regime da escravidão doméstica, o cristianismo cruzou-se com o fetichismo, como se cruzaram as duas raças. Pela influência da ama-de-leite e dos escravos de casa sobre a educação da criança, os terrores materialistas do fetichista convertido, isto é, que mudou de inferno, exercem, sobre a fortificação do cérebro e a coragem da alma daquelas, a maior depressão. $\mathrm{O}$ que resulta como fé, e sistema religioso, dessa combinação das tradições africanas como o ideal antissocial do missionário fanático, é um composto de contradições, que só a inconsciência pode conciliar. Como a religião, a Igreja.

Nem os bispos, nem os vigários, nem os confessores, estranham o mercado de entes humanos; as bulas que o condenam são hoje obsoletas. Dois dos nossos prelados foram sentenciados a prisão com trabalho, pela guerra que moveram à Maçonaria; nenhum deles, porém, aceitou ainda a responsabilidade de descontentar a escravidão. Compreende-se que os exemplos dos profetas, penetrando no palácio dos reis de Judá para exprobar-lhes os seus crimes, e os sofrimentos dos antigos mártires pela verdade moral, pareçam aos que representam a religião entre nós 
originalidades tão absurdas como a de São Simeão Estelita vivendo no tope de uma coluna para estar mais perto de Deus. Mas, se o regime da côngrua e dos emolumentos, mais do que isso, das honras oficiais e do bem estar, não consente esses rasgos de heroísmo religioso, hoje próprios, tão somente, de um faquir do Himalaia, apesar desse resfriamento glacial de uma parte da alma outrora incandescente, a escravidão e o Evangelho deviam mesmo hoje ter vergonha de se encontrarem na casa de Jesus e de terem o mesmo sacerdócio.

Nem quanto aos casamentos dos escravos, nem por sua educação moral, tem a Igreja feito coisa alguma. Os monges de São Bento forraram seus escravos, e isso produziu entre os panegiristas dos conventos uma explosão de entusiasmo. Quando mosteiros possuem rebanhos humanos, quem conhece a história das fundações monásticas, os votos dos noviços, o desinteresse das suas aspirações, a sua abnegação pelo mundo, só pode admirar-se de que esperem reconhecimento e gratidão por terem deixado de tratar homens como animais, e de explorar mulheres como máquinas de produção.

Se em relação às pessoas livres mesmo - oficiou em 1864 ao governo o cura da freguesia do Sacramento da Corte - se observa o abandono, a indiferença atinge o escândalo em relação aos escravos. Poucos senhores cuidam em proporcionar aos seus escravos em vida os socorros espirituais; raros são aqueles que cumprem com o caridoso dever de lhes dar os derradeiros sufrágios da Igreja. ${ }^{48}$

Grande número de padres possuem escravos, sem que o celibato clerical o proíba. Esse contato, ou antes contágio, da escravidão, deu à religião, ente nós, o caráter materialista que ela tem, destruiu-lhe a face ideal, e tirou-lhe toda a possibilidade de desempenhar na vida social do país o papel de uma força consciente.

Tome-se outro elemento de conservação que também foi apropriado dessa forma, o patriotismo. O trabalho todo dos escravagistas consistiu sempre em identificar o Brasil com a escravidão. Quem a ataca é logo suspeito de conivência com o estrangeiro, de inimigo das instituições do seu próprio país. Antônio Carlos foi acusado nesse interesse de não ser brasileiro. Atacar a monarquia, sendo o país monárquico, a religião sendo o

${ }^{48}$ Consultas do Conselho de Estado sobre Negócios Eclesiásticos. Consulta de 18 de junho de 1864 . país católico, é lícito a todos; atacar, porém, a escravidão, é traição nacional e felonia. Nos Estados Unidos, "a instituição particular" por tal forma criou em sua defesa essa confusão, entre si e o país, que pôde levantar uma bandeira sua contra a de Washington, e produzir, numa loucura transitória, um patriotismo separatista desde que se sentiu ameaçada de cair deixando a pátria de pé. Mas, como com todos os elementos morais que avassalou, a escravidão ao conquistar o patriotismo brasileiro fê-lo degenerar. A guerra do Paraguai é a melhor prova do que ela fez ao patriotismo das classes que a praticavam, e do patriotismo dos senhores. Muito pouco desses deixaram os seus escravos para atender ao seu país; muitos alforriaram alguns "negros" para serem eles feitos titulares do Império. Foi nas camadas mais necessitadas da população descendente de escravos na maior parte, nessas mesmas que a escravidão condena à dependência e à miséria, entre os proletários analfabetos cuja emancipação política ela adiou indefinidamente, que se sentiu bater o coração de uma nova pátria. Foram elas que produziram os soldados dos batalhões de voluntários. Com a escravidão, disse José Bonifácio em 1825, "nunca o Brasil formará, como imperiosamente o deve, um exército brioso e uma marinha florescente", e isso porque com a escravidão, não há patriotismo nacional, mas somente patriotismo de casta, ou de raça; isto é, um sentimento que serve para unir todos os membros da sociedade, é explorado para o fim de dividi-los. Para que o patriotismo se purifique, é preciso que a imensa massa da população livre, mantida em estado de subserviência pela escravidão, atravesse, pelo sentimento da independência pessoal, pela convicção da sua força e do seu poder, o longo estádio que separa o simples nacional - que hipoteca tacitamente, por amor, a sua vida à defesa voluntária da integridade material e da soberania externa da pátria - do cidadão que quer ser uma unidade ativa e pensante na comunhão a que pertence.

Entre as forças em torno de cujo centro de ação o escravagismo fez o vácuo, por lhe serem contrárias, forças de progresso e transformação, está novamente a imprensa, não só o jornal, mas também o livro, tudo que diz respeito à educação. Por honra do nosso jornalismo, a imprensa tem sido a grande arma de combate contra a escravidão e o instrumento da propagação das ideias novas; os esforços tentados para a criação de um órgão negro naufragaram sempre. Ou se insinue timidamente, ou se afirme com energia, o pensamento dominante no jornalismo todo, de Norte ao Sul, é a emancipação. Mas, para fazer o vácuo em torno do jornal e do livro, e de tudo que pudesse 
amadurecer antes do tempo a consciência do abolicionista, a escravidão por instinto procedeu repelindo a escola, a instrução pública, e mantendo o país na ignorância e escuridão, que é o meio em que ela pode prosperar. A senzala e a escola são polos que se repelem.

O que é a educação nacional num regime interessado na ignorância de todos, o seguinte trecho do notável parecer do Sr. Rui Barbosa, relator da Comissão de Instrução Pública da Câmara dos Deputados, o mostra bem:

A verdade - e a vossa Comissão quer ser muito explícita a seu respeito, desagrade a quem desagradar - é que o ensino público está à orla do limite possível a uma nação que se presume livre e civilizada; é que há decadência em vez de progresso; é que somos um povo de analfabetos, e que a massa deles, se decresce, é numa proporção desesperadamente lenta; é que a instrução acadêmica está infinitamente longe do nível científico desta idade; é que a instrução secundária oferece ao ensino superior uma mocidade cada vez menos preparada para o receber; é que a instrução popular, na Corte como nas províncias, não passa de um desideratum.

Aí está o efeito, sem aparecer a causa, como em todos os inúmeros casos em que os efeitos da escravidão são apontados entre nós. Um lavrador fluminense, por exemplo, o Sr. Paes Leme, foi em 1876 aos Estados Unidos comissionado pelo nosso governo. Escreveu relatórios sobre o que viu e observou na América do Norte, pronunciou discursos na Assembleia Provincial do Rio de Janeiro, que são ainda o resultado daquela viagem, e nunca lhe ocorreu, nos diferentes paralelos que fez entre o Estado do Brasil e o da grande República, atribuir à escravidão uma parte sequer do nosso atraso. $\mathrm{O}$ mesmo dá-se com toda a literatura política, liberal ou republicana, em que um fator da ordem da escravidão figura como um órgão rudimentar e inerte.

Entre as forças cuja aparição ela impediu está a opinião pública, a consciência de um destino nacional. Não há, com a escravidão, essa força poderosa chamada opinião pública, ao mesmo tempo alavanca e o ponto de apoio das individualidades que representam o que há de mais adiantado no país. A escravidão, como é incompatível com a imigração espontânea, também não consente o influxo das ideias novas. Incapaz de invenção, ela é, igualmente, refratária ao progresso. Não é dessa opinião pública que sustentou os negreiros contra os Andradas, isto é, da soma dos interesses coligados que se trata, porque essa é uma força bruta e inconsciente como a do número por si só. Duzentos piratas valem tanto quanto um pirata, e não ficarão valendo mais se os cercarem da população toda que eles enriquecem e da que eles devastam. A opinião pública, de que falo, é propriamente a consciência nacional, esclarecida, moralizada, honesta, e patriótica; essa é impossível com a escravidão, e desde que apareça, esta trata de destruí-la.

É por não haver entre nós essa força de transformação social que a política é a triste e degradante luta por ordenados, que nós presenciamos; nenhum homem vale nada, porque nenhum é sustentado pelo país. O presidente do Conselho vive à mercê da Coroa, de quem deriva a sua força, e só tem aparência do poder quando se o julga um lugar tenente do imperador e se acredita que ele tem no bolso o decreto de dissolução, isto é, o direito de eleger uma câmara de apaniguados seus. Os ministros vivem logo abaixo, à mercê do presidente do Conselho, e os deputados no terceiro plano, à mercê dos ministros. O sistema representativo é, assim, um enxerto de formas parlamentares num governo patriarcal, e senadores e deputados só tomam a sério o papel que lhes cabe nessa paródia da democracia pelas vantagens que auferem. Suprima-se o subsídio, e forcem-nos a não se servirem de sua posição para fins pessoais e de família, e nenhum homem que tenha o que fazer se prestará a perder o seu tempo em tais skiamaxiai, em combates com sombras, para tomar uma comparação com Cícero.

Ministros, sem apoio na opinião, que ao serem despedidos caem no vácuo; presidentes do Conselho que vivem, noite e dia, a perscrutar o pensamento esotérico do imperador; uma Câmara cônscia da sua nulidade e que só pede tolerância; um Senado que se reduz a um ser pritaneu; partidos que são apenas sociedades cooperativas de colocação ou de seguro contra a miséria. Todas essas aparências de um governo livre são preservadas por orgulho nacional, como foi a dignidade consular no Império Romano; mas, no fundo, o que temos é um governo de uma simplicidade primitiva, em que as responsabilidades se dividem ao infinito, e o poder está concentrado nas mãos de um só. Este é o chefe do Estado. Quando alguém parece ter força própria, autoridade efetiva, prestígio individual, é porque lhe acontece, nesse momento, estar exposto à luz do trono: desde que der um passo, ou à direita ou à esquerda, e sair daquela réstia, ninguém mais o divisará no escuro.

Foi a isso que a escravidão, como causa infalível de corrupção social, e pelo seu terrível contágio, reduziu a nossa política. O povo como que sente um prazer cruel em escolher o pior, isto é, em rebaixar-se a si mesmo, 
por ter consciência de que é uma multidão heterogênea, sem disciplina a que se sujeite, sem fim que se proponha. A municipalidade da Corte, do centro da vida atual da nação toda, foi sempre eleita por esse princípio. Os capangas no interior, e nas cidades os capoeiras, que também têm a sua flor, fizeram até ontem das nossas eleições o jubileu do crime. A faca de ponta e a navalha, exceto quando a baioneta usurpava essas funções, tinham sempre a maioria nas urnas. Com a eleição direta, tudo isso desapareceu na perturbação do primeiro momento, porque houve um ministro de vontade, que disse aspirar à honra de ser derrotado nas eleições. O Sr. Saraiva, porém, já foi canonizado pela sua abnegação; já tivemos bastante ministrosmártires para formar o hagiológico da reforma, e ficou provado que nem mesmo é preciso a candidatura oficial para eleger câmaras governistas. A máquina eleitoral é automática, e, por mais que mudem a lei, o resultado há de ser o mesmo. O capoeira conhece o seu valor, sabe que não passam tão depressa como se acredita os dias de Clódio, e em breve a eleição direta será o que foi a indireta: a mesma orgia desenfreada a que nenhum homem decente devera, sequer, assistir.

Autônomo, só há um poder entre nós, o poder irresponsável; só esse tem a certeza do dia seguinte; só esse representa a permanência da tradição nacional. Os ministros não são mais que as encarnações secundárias, e às vezes grotescas, dessa entidade superior. Olhando em torno de si, o imperador não encontra uma só individualidade que limite a sua, uma vontade individual ou coletiva, a que ele se deva sujeitar: nesse sentido ele é absoluto como o czar e o sultão, ainda que se veja no centro de um governo moderno e provido de todos os órgãos superiores, como o parlamento, que não tem a Rússia nem a Turquia, a supremacia parlamentar, que não tem a Alemanha, a liberdade absoluta da imprensa, que muitos poucos países conhecem. Quer isso dizer, em vez de soberano absoluto, o imperador deve antes ser chamado o primeiro-ministro permanente do Brasil. Ele não comparece perante as Câmaras, deixa grande latitude, sobretudo em matéria de finanças e legislação, ao gabinete; mas nem um só dia perde de vista a marcha da administração, nem deixa de ser o árbitro dos seus ministros.

Esse chamado governo pessoal é explicado pela teoria absurda de que o imperador corrompeu um povo inteiro; desmoralizou por meio de tentações supremas, à moda de Satanás, a honestidade dos nossos políticos; desvirtuou, intencionalmente partidos que nunca tiveram ideias e princípios, senão como capital de exploração. A verdade é que esse governo é o resultado, imediato, da prática da escravidão pelo país. Um povo que se habitua a ela não dá valor à liberdade, nem aprende a governar-se a si mesmo. Daí a abdicação geral das funções cívicas, o indiferentismo político, o desamor pelo exercício obscuro e anônimo da responsabilidade pessoal, sem a qual nenhum povo é livre, porque um povo livre é somente um agregado de unidades livres: causas que deram em resultado a supremacia do elemento permanente e perpétuo, isto é, a Monarquia. O imperador não tem culpa, exceto, talvez, por não ter reagido contra essa abdicação nacional, de ser tão poderoso como é, tão poderoso que nenhuma delegação da sua autoridade, atualmente, conseguiria criar no país uma força maior que a Coroa.

Mas, por isso mesmo, Dom Pedro II será julgado pela História como o principal responsável pelo seu longo reinado; tendo sido o seu próprio valido durante quarenta e três anos, ele nunca admitiu presidentes do Conselho superiores à sua influência e, de fato, nunca deixou o leme (com relação a certos homens que ocuparam aquela posição, foi talvez melhor para eles mesmos, o serem objetos desse liberum veto). Não é assim, como soberano constitucional, que o futuro há de considerar o imperador, mas como estadista; ele é um Luís Felipe, e não uma rainha Vitória - e ao estadista hão de ser tomadas estreitas contas da existência da escravidão, ilegal e criminosa, depois de um reinado de quase meio século. O Brasil despendeu mais de seiscentos mil contos em uma guerra politicamente desastrosa, e só tem despendido, até hoje, nove mil contos em emancipar os seus escravos: tem um orçamento seis vezes apenas menor do que a Inglaterra, e desse orçamento menos de um por cento é empregado em promover a emancipação.

Qualquer, porém, que seja, quanto à escravidão, a responsabilidade pessoal do imperador, não há dúvida de que a soma do poder que foi acrescendo à sua prerrogativa foi uma aluvião devida àquela causa perene. No meio da dispersão das energias individuais e das rivalidades dos que podem servir à pátria, levanta-se, dominado as tendas dos agiotas políticos e os antros dos gladiadores eleitorais, que cercam o nosso Forum, a estátua do imperador, símbolo do único poder nacional independente e forte. 
Mas em toda essa dissolução social, na qual impera o mais ávido materialismo, e os homens de bem e patriotas estão descrentes e tudo e de todos, quem não vê a forma colossal da raça maldita, sacudindo os ferros dos seus pulsos, espalhando sobre o país as gotas do seu sangue? Essa é a vingança da raça negra. Não importa que tantos dos seus filhos espúrios tenham exercido sobre irmãos o mesmo jugo, e se tenham associado como cúmplices aos destinos da instituição homicida, a escravidão na América é sempre o crime da raça branca, elemento predominante da civilização nacional, e esse miserável estado, a que se vê reduzida a sociedade brasileira, não é senão o cortejo da Nêmesis africana que visita, por fim, o túmulo de tantas gerações. 